УдК $351.74+519.72$

B. О. Негодченко

\title{
МЕТОДИ ЗАБЕЗПЕЧЕННЯ ДЕРЖАВНОЇ ІНФОРМАЦЙНОЇ ПОЛІТИКИ ОРГАНАМИ ВНУТРІШНІХ СПРАВ
}

Постановка проблеми. Сучасний етап розвитку суспільства характеризується зростаючою роллю інформаційної сфери, що являє собою сукупність інформації, інформаційної інфраструктури, суб'єктів, що здійснюють збирання, формування, поширення й використання інформації, а також системи регулювання суспільних відносин, що виникають при цьому. Інформаційна сфера $є$ системоутворюючим чинником життя суспільства, активно впливає на стан політичної, економічної, оборонної й інших складових безпеки держави. У зв'язку із цим є необхідним дослідження питання методів забезпечення державної інформаційної політики відповідними суб’єктами публічної адміністрації. Специфіка методів, що використовуються, значно залежить від суб'єкта діяльності, об'єкта впливу, а також цілей, що переслідуються. Так, методи діяльності індивіда у зв'язку з його обмеженою можливістю щодо забезпечення інформаційної безпеки здебільшого зводяться до джерела загрози, апелювання до суспільної думки, а також до держави, яка має вживати рішучих заходів із нейтралізації інформаційних загроз. Саме суспільство частково використовує у своїй діяльності методи соціального регулювання, надання допомоги окремим індивідам і суспільним організаціям, яким спричинена шкода внаслідок виявлення загрози.

Стан дослідження. Науковий фундамент для вивчення методів забезпечення державної інформаційної політики в Україні органами внутрішніх справ становлять праці таких провідних учених, як В.Б. Авер'янов, I.В. Арістова, О.М. Бандурка, О.І. Безпалова, К.І. Бєляков, О.В. Джафарова, О.Ю. Дрозд, Р.А. Калюжний, В.К. Колпаков, В.А. Ліпкан, О.В. Негодченко, Г.Г. Почепцов, В.П. Тимошук, В.О. Шамрай, С.О. Шатрава, А.О. Чемерис та інші. Саме ці праці покладено в основу формування підходу щодо визначення методів діяльності органів внутрішніх справ щодо забезпечення державної інформаційної політики в Україні.

Виклад основного матеріалу. Державна інформаційна політка нами розуміється як головний напрям і предмет діяльності держави в галузі інформації з метою створення умов для ефективного та якісного інформаційного 
забезпечення стратегічних і оперативних завдань соціального й економічного розвитку держави. 3 метою реалізації зазначеного органи внутрішніх справ відіграють важливу роль в усуненні певних загроз, а саме обмеження свободи слова та доступу громадян до інформації, руйнування системи цінностей, духовного й фізичного здоров'я особи, суспільства, негативні зміни їх цільових настанов; маніпулювання громадською думкою; обмеження можливостей органів державної влади щодо ухвалення адекватних рішень; спотворення інформаційних ресурсів, програмного забезпечення [1, с. 167].

Отже, діяльність органів внутрішніх справ із забезпечення державної інформаційної політики здійснюється за допомогою різних способів, засобів і прийомів, які у своїй органічній сукупності складають методи. Метод передбачає певну послідовність дій на підставі конкретного плану. Методи можуть значно змінюватися й варіюватися залежно від типу діяльності, у якій вони використовуються, а також сфери застосування [2, с. 167-168].

Тому з метою виокремлення основних методів забезпечення державної інформаційної політики органами внутрішніх справ вважаємо за необхідне, по-перше, розглянути загальну концепцію щодо розуміння методів у діяльності органів внутрішніх справ, а по-друге, дослідити специфіку реалізації останніх щодо забезпечення державної інформаційної політики.

Як наголошує Т.О. Коломоєць, термін «метод» у загальноприйнятому розумінні означає способи чи прийоми здійснення чого-небудь, засіб досягнення поставленої мети. Відповідно до цього методи публічної адміністрації - це сукупність засобів здійснення управлінських і публічно-сервісних функцій держави, впливу суб'єктів публічної адміністрації на об'єкти. У свою чергу особливостями методів публічної адміністрації $є$ такі: реалізуються в процесі публічної адміністрації; виражають керівний (упорядковуючий) вплив суб'єктів публічної адміністрації на об'єкти адміністрування, $є$ змістом цього впливу й завжди мають своїм адресатом конкретний об’єкт; у методах публічної адміністрації міститься воля держави, виражаються повноваження владного характеру органів виконавчої влади; використовуються суб'єктами публічної адміністрації як засіб реалізації їх компетенції; мають свою форму й зовнішнє вираження; у методах знаходить прояв публічний інтерес; вибір конкретного методу залежить від сукупності факторів, у тому числі від особливостей організаційно-правового статусу суб̆єкта пуб̆лічної адміністрації, від об'єкта його діяльності [3, с. 193].

Водночас В.К. Колпаков зазначає, що в загальноприйнятому розумінні термін «метод» означає спосіб чи прийом здійснення чого-небудь. Виходячи із цього, під методами будь-якої діяльності треба розуміти способи, прийоми, засоби, які використовуються для досягнення поставленої мети та становлять зміст цієї діяльності [4, с. 180].

У свою чергу Ю.П. Битяк, В В. Зуй наголошують, що в державному управлінні під методами розуміють засоби практичної реалізації завдань і функцій діяльності суб'єктів управління. Інакше кажучи, метод управління - це спосіб здійснення управлінських функцій, впливу суб'єкта управління на об’єкт (колектив, групу осіб чи окрему особу) [5, с. 72]. 
Зокрема, А.Т. Комзюк методи адміністративної діяльності органів внутрішніх справ визначає як різноманітні засоби, прийоми та способи, за допомогою яких останні здійснюють вплив на суспільні відносини з метою реалізації своїх правоохоронних завдань і функцій [6, с. 19].

O.I. Безпалова наголошує, що ключовими методами реалізації правоохоронної функції держави є адміністративні, економічні та соціально-психологічні. Учений доводить, що в рамках адміністративних методів реалізації правоохоронної функції держави окремі суб'єкти можуть застосовувати методи переконання та примусу; прогнозування та планування, координації, субординації, методи перевірки, заслуховування й аналізу інформації, узагальнення матеріалів тощо. Крім того, застосування відповідних адміністративних методів під час реалізації правоохоронної функції держави залежить від суб'єкта, на який покладено обов'язок щодо реалізації цієї функції, його завдань і повноважень [7, с. 142].

Позиція О.I. Безпалової базується на теоретичних напрацюваннях О.М. Бандурки та В.М. Плішкіна, які, здійснюючи класифікацію методів управління залежно від характеру (змісту) впливу, розрізняють адміністративні (організаційно-розпорядчі), економічні [8, с. 347] та соціально-психологічні [9, с. 145-151]. Такої ж позиції дотримуються автори навчального посібника «Публічне адміністрування в Україні», які за змістовною характеристикою виокремлюють такі групи методів: правового регулювання, організаційно-розпорядчі (адміністративні), економічні, соціально-політичні, соціально-психологічні та морально-етичні [10].

Зазначеної позиції дотримується Л.О. Євдоченко під час визначення методів державного забезпечення інформаційної безпеки України, поділяючи їх на правові, організаційно-технічні й економічні [11].

У свою чергу С.О. Шатрава наголошує на тому, що незалежно від змісту та спрямованості методам адміністративної діяльності органів внутрішніх справ властиві такі риси: організаційна форма, під якою розуміється вид впливу, тобто управлінсько-розпорядчі розпорядження (наказ, вимога тощо); характер впливу (безпосередній вплив, непрямий вплив за допомогою створення стимулюючих умов або умов, що обмежують); засіб впливу (одноособовий, колегіальний, колективний); тимчасова характеристика (короткострокові й довгострокові); наявність тактичного та стратегічного характеру. Отже, методи адміністративної діяльності ОВС, як і форми, досить різноманітні та покликані забезпечити високу ефективність діяльності працівників ОВС, злагодженість роботи, сприяти розвитку творчої ініціативи кожного співробітника [12, с. 132].

У попередніх наукових працях ми звертали увагу на введення в правовий обіг терміна «інструменти діяльності органів публічної адміністрації» для позначення саме зовнішньої діяльності останніх щодо реалізації завдань і функцій, які покладені на зазначений орган [13]. У цьому випадку категорія «інструменти діяльності органів публічної адміністрації» поглинає категорію «методи діяльності органів публічної адміністрації.

Із цього приводу варто назвати працю М.Л. Пахніна, який наголошує, що українське суспільство та держава в сучасних умовах украй потребу- 
ють цілеспрямованої інформаційної політики, яка б, з одного боку, забезпечувала потреби кожної людини в інформації, надаючи їй усебічний i гармонійний розвиток, а з іншого - слугувала б ефективним інструментом захисту національної безпеки та територіальної цілісності України. При цьому дослідник наголошує, що державна інформаційна політика реалізується за допомогою фінансових і нефінансових інструментів. До фінансових інструментів відноситься пряма державна підтримка суб'єктів інформаційної сфери; надання податкових, митних та інших пільг; бюджетні дотації тощо. Нефінансові інструменти включають власну інформаційну діяльність держави; розвиток усіх видів державних засобів масової інформації; удосконалення законодавства в інформаційній сфері, що регулює діяльність недержавних суб'єктів; діяльність щодо розвитку інформаційної інфраструктури; діяльність щодо налагодження співпраці з різними суб'єктами інформаційної сфери [14].

Варто звернути увагу на позицію В.А. Ліпкана, який наголошує, що інформаційна безпека виступає інструментарієм для втілення інформаційної політики, а відтак державна політика інформаційної безпеки є складовим компонентом інформаційної політки держави [2, с. 151]. У зв'язку із цим доречно звернутися до методів забезпечення інформаційної безпеки. Так, В.А. Ліпкан наголошує, що важливими методами аналізу стану забезпечення інформаційної безпеки є методи опису та класифікації. Як розповсюджені методи аналізу стану забезпечення інформаційної безпеки використовуються методи дослідження причинних зв'язків. За допомогою цих методів виявляються причинні зв'язки між загрозами, ризиками, викликами й небезпеками; здійснюється пошук причин, які стали джерелом i спричинили актуалізацію тих чи інших чинників небезпеки, а також розробляються заходи з їх нейтралізації. Серед цих методів причинних зв'язків можна назвати такі: метод схожості, метод відмінності, метод сполучення схожості й відмінності, метод змін, що супроводжують, метод залишків.

Вибір методів аналізу стану забезпечення інформаційної безпеки залежить від конкретного рівня та сфери організації захисту. Залежно від загрози уможливлюється завдання щодо диференціації як різних рівнів загроз, так і різних рівнів захисту. Що стосується сфери інформаційної безпеки, то і ній зазвичай виділяють: фізичний, програмно-технічний, управлінський, технологічний, рівень користувача, мережний, процедурний [2, с. 168].

Погоджуючись із позицією В.А. Ліпкана, доречно виокремити декілька типів методів забезпечення інформаційної безпеки: 1) однорівневі методи, що будуються на підставі одного принципу управління інформаційною безпекою; 2) багаторівневі методи, які будуються на основі декількох принципів управління інформаційною безпекою, кожний із яких слугує вирішення власного завдання. При цьому приватні технології не пов'язані між собою та спрямовані лише на конкретні чинники інформаційних загроз; 3) комплексні методи - багаторівневі технології, які об'єднані в єдину систему координуючими функціями на організаційному рівні з метою забезпечення інформаційної безпеки, виходячи з аналізу сукупності чинників небезпеки, які мають семантич- 
ний зв'язок або генеруються з єдиного інформаційного центру інформаційного впливу; 4) інтегровані високоінтелектуальні методи - багаторівневі, багатокомпонентні технології, які побудовані на підставі могутніх автоматизованих інтелектуальних засобів з організаційним управлінням [2, с. 169-170].

Враховуючи викладене, вважаємо, що методи забезпечення державної інформаційної політки можна поділити на правові, організаційно-технічні й економічні.

До правових методів забезпечення інформаційної політки належить розробка нормативних правових актів, що регламентують відносини в інформаційній сфері, і нормативних методичних документів із питань забезпечення інформаційної безпеки України. Найважливішими напрямами цієї діяльності $€$ внесення змін і доповнень до законодавства України, що регулює відносини в галузі забезпечення інформаційної безпеки з метою створення й удосконалення системи забезпечення інформаційної безпеки України, усунення внутрішніх протиріч у державному законодавстві, протиріч, пов'язаних із міжнародними угодами, до яких приєдналася Україна, а також із метою конкретизації правових норм, що встановлюють відповідальність за правопорушення в галузі забезпечення інформаційної безпеки України; законодавче розмежування повноважень у галузі забезпечення інформаційної безпеки України між органами державної влади, визначення цілей, завдань і механізмів участі в цій діяльності громадських об’єднань, організацій і громадян; розробка та прийняття нормативних правових актів України, які встановлюють відповідальність юридичних і фізичних осіб за несанкціонований доступ до інформації, іï протиправне копіювання, перекручування й протизаконне використання, навмисне поширення недостовірної інформації, протиправне розголошення інформації з обмеженим доступом, використання в злочинних і корисливих цілях службової інформації чи інформації, що містить комерційну таємницю; уточнення статусу іноземних інформаційних агентств, засобів масової інформації та журналістів, а також інвесторів під час залучення іноземних інвестицій для розвитку інформаційної інфраструктури України; законодавче закріплення пріоритету розвитку національних мереж зв'язку й вітчизняного виробництва космічних супутників зв'язку; визначення статусу організацій, що надають послуги глобальних інформаційно-телекомунікаційних мереж на території України, і правове регулювання діяльності цих організацій; створення правової бази для формування в Україні системи забезпечення інформаційної безпеки, зокрема ії центральних органів і регіональних структур [1, с. 344].

Організаційно-технічними методами забезпечення державної інформаційної політики в Україні є створення й удосконалення системи забезпечення інформаційної безпеки України; посилення діяльності державних органів виконавчої влади із застосування правових норм, включаючи попередження та припинення правопорушень в інформаційній сфері, а також виявлення, викриття та притягнення до відповідальності осіб, що скоїли кримінальні правопорушення та інші правопорушення в цій сфері; розробка, використання й удосконалення засобів захисту інформації й методів 
контролю ефективності цих засобів, розвиток захищених телекомунікаційних систем, підвищення надійності спеціального програмного забезпечення; створення систем і засобів запобігання несанкціонованому доступу до інформації, що обробляється, і спеціальним впливам, які призводять до руйнування; знищення, спотворення інформації, а також зміна штатних режимів функціонування систем і засобів та зв'язку; виявлення технічних пристроїв і програм, що загрожують нормальному функціонуванню інформаційно-телекомунікаційних систем, запобігання перехопленню інформації в технічних каналах іï витоку, застосування криптографічних засобів захисту інформації під час іiі обробки та передачі каналами зв'язку, контроль за виконанням спеціальних вимог із захисту інформації; сертифікація засобів захисту інформації, ліцензування діяльності в галузі захисту інформації, стандартизація способів і засобів іiі захисту; удосконалення системи сертифікації телекомунікаційного обладнання та програмного забезпечення автоматизованих систем обробки інформації на відповідність вимогам із захисту інформації; контроль за діями персоналу в захищених інформаційних системах, підготовка кадрів у галузі забезпечення інформаційної безпеки України; формування системи моніторингу показників і характеристик інформаційної безпеки України у найважливіших сферах життя й діяльності суспільства та держави [1, с. 344].

У свою чергу економічні методи забезпечення державної інформаційної політики в Україні містять розробку програм забезпечення інформаційної безпеки України й визначення порядку іх фінансування; удосконалення системи фінансування робіт із реалізації правових та організаційно-технічних методів захисту інформації, створення системи страхування інформаційних ризиків фізичних і юридичних осіб [1, с. 345].

Висновки. У цілому варто зазначити, що обрання цілей і методів протидії конкретним загрозам інформаційній безпеці є важливою проблемою та складову частину діяльності органів внутрішніх справ із реалізації основних напрямів державної інформаційної політики.

\section{Література}

1. Богуш В.М. Інформаційна безпека держави : [навчальний посібник] / В.М. Богуш, О.К. Юдін. - К. : МК-Прес, 2005. - 432 с.

2. Ліпкан В.А. Інформаційна безпека України в умовах євроінтеграції : [навчальний посібник] / В.А. Ліпкан, Ю.Є. Максименко, В.М. Желіховський. - К. : КНТ, 2006. - 280 с.

3. Коломоєць Т.О. Адміністративне право України. Академічний курс : [підручник] / Т.О. Коломоєць. - К. : Юрінком Інтер, 2011. - 576 с

4. Колпаков В.К. Адміністративне право України : [підручник] / В.К. Колпаков, О.В. Кузьменко. - К. : Юрінком Інтер, 2003. - 544 с.

5. Битяк Ю.П. Адміністративне право України : [конспект лекцій] / Ю.П. Битяк, В.В. Зуй. - Х. : Нац. юрид. акад. України імені Ярослава Мудрого, 1996. - 160 с.

6. Комзюк А.Т. Заходи адміністративного примусу в правоохоронній діяльності міліції: поняття, види та організаційно-правові питання реалізації : [монографія] / А.Т. Комзюк. - Х. : HУBC, 202. - 336 c.

7. Безпалова О.І. Адміністративно-правовий механізм реалізації правоохоронної функції держави : [монографія]. / О.І. Безпалова. - Х. : НікаНова, 2014. - 544 с.

8. Адміністративне право України. Загальна частина. Академічний курс : [підручник] / за ред. О.М. Бандурки. - Х. : Золота миля, 2011. - 584 с. 
9. Плішкін В.М. Теорія управління органами внутрішніх справ : [підручник] / В.М. Плішкін ; за ред. Ю.Ф. Кравченка. - К. : НАВС, 1999. - 720 с.

10. Публічне адміністрування в Україні : [навчальний посібник] / [В.Б. Дзюндзюк, Н.М. Мельтюхова, Н.В. Фоміцька ] ; за заг. ред. В.В. Корженка, Н.М. Мельтюхової. - Х. : Магістр, 2011. - 306 с.

11. Євдоченко Л.О. Шляхи та методи державного забезпечення інформаційної безпеки України: теоретичний аспект / Л.О. Євдоченко // Демократичне врядування. - 2010. Вип. 5. - [Електронний ресурс]. - Режим доступу : http://www.lvivacademy.com/ vidavnitstvo_1/visnik5/fail/+Jevdoch.pdf.

12. Шатрава С.О. Адміністративно-правові засади діяльності спеціальних підрозділів міліції : дис. ... канд. юрид. наук : спец. 12.00.07 / С.О. Шатрава. - Х., 2007. - 231 с.

13. Патерило I.В. Інститут інструментів діяльності публічної адміністрації у системі адміністративного права України / I.В. Патерило / / Науковий вісник Дніпропетровського державного університету внутрішніх справ. - 2013. - № 1. - С. 283-289.

14. Пахнін М.Л. Принципи, завдання та інструменти державної інформаційної політики України в сучасних умовах / М.Л. Пахнін / / Теорія та практика державного управління. - 2014. - Вип. 3(46). [Електронний ресурс]. - Режим доступу : http://search.ukr.net/?go=http $\% 3 \mathrm{~A} \% 2 \mathrm{~F} \% 2 \mathrm{Fwww}$. kbuapa. kharkov.ua \%2Fe-book\%2Ftpdu \%2F2014-3\%2Fdoc \%2F1\%2F12.pdf.

\section{Анот а ц і я}

Негодченко B. О. Методи забезпечення державної інформаційної політики органами внутрішніх справ. - Стаття.

У статті з метою виокремлення основних методів забезпечення державної інформаційної політики органами внутрішніх справ розглянуто загальну концепцію щодо розуміння методів у діяльності органів внутрішніх справ, а також досліджено специфіку реалізації останніх щодо забезпечення державної інформаційної політики. Здійснено класифікацію методів забезпечення державної інформаційної політики на правові, організаційно-технічні й економічні.

Ключові слова: державна інформаційна політика, інформаційна безпека, інформаційна сфера, органи внутрішніх справ, методи, інструменти.

\section{А н н о т а ци я}

Негодченко В. А. Методы обеспечения государственной информационной политики органами внутренних дел. - Статья.

В статье с целью выделения основных методов обеспечения государственной информационной политики органами внутренних дел рассмотрена общая концепция относительно понимания методов в деятельности органов внутренних дел, а также исследована специфика реализации последних по обеспечению государственной информационной политики. Осуществлена классификация методов обеспечения государственной информационной политики на правовые, организационно-технические и экономические.

Ключевые слова: государственная информационная политика, информационная безопасность, информационная сфера, органы внутренних дел, методы, инструменты.

\section{S u m m a r y}

Nehodchenko $V$. O. Methods of providing public information policy by enforcement bodies. - Article.

In an article for the purpose of isolating the main methods of state information policy enforcement bodies, considered overall concept in understanding methods in the work of the police and investigated the specific implementation of the past for providing information policy. Classification methods of state information policy on legal, organizational, technical and economic.

Key words: public information policy, information security, information sphere, internal affairs bodies, methods and tools. 